\title{
Production Method and Humic Acid Application Affect Hardening-Off Process and Landscape Performance of Platycladus Orientalis in Arid Climate
}

\author{
Nematollah Etemadi and Rezvan Mohammadi Nezhad
}

\begin{abstract}
The scarcity of information regarding suitable conditions for tree transplanting in arid climates is a major cause for failure of most transplanting projects. This study investigated the effect of different transplant methods and biostimulant application on survival and growth of multi-purpose species oriental thuja (Platycladus orientalis). In the first experiment, trees were harvested bare-root (BR) or balled and burlapped (B\&B) and hardened-off in containers for one year prior to transplanting. In the second experiment, post-transplant performance of hardened-off trees in containers (referred to as CG tress) were compared to freshly dug BR and B\&B trees. In both experiments, half of the trees were treated with $300 \mathrm{mg} / \mathrm{L}$ of humic acid (HA). In contrast to the B\&B trees, the BR trees did not successfully tolerate the hardening-off process. During the first year following transplanting to the landscape, CG trees showed $100 \%$ survival and achieved significant increases in all measured parameters compared to B\&B and BR trees. By the end of the second year, however, the significant advantage of CG trees over B\&B tress vanished, and the growth rates of trees of both methods were equaled to non-transplanted trees, suggesting that final performance for hardened-off CG trees and conventionally B\&B-transplanted trees may be similar. HA application only affected BR trees, so that HA-treated BR trees had greater survival and growth indices than their control counterparts. In general, in an arid climate, the landscape manager would obtain the most cost-effective and reliable transplanting method by planting B\&B thujas with no necessity for a hardening-off period and incorporation of stimulants.

Key Words. Balled and Burlapped; Bare Root; Hardening-Off; Humic Acid; Production Method; Tree Establishment; Platycladus Orientalis.
\end{abstract}

Root loss and damage, following harvesting, handling, or storage of the plant material are the main reasons for low vitality and growth after transplanting. Damaged roots restrict the capacity for supplying required water and nutrients for newly planted tree (Percival and Barnes 2004; Apostol et al. 2009). Therefore, developing management strategies that potentially promote rapid resumption of root growth and minimize stress are crucial for the establishment, survival, and subsequent growth of transplanted trees.

Production method is a decisive factor that affects post-transplant establishment by influencing the volume of root loss during harvesting. Fieldgrown (FG) trees, harvested either as bare root (BR) or balled and burlapped (B\&B), have more uniform root distribution compared to container-grown (CG) trees, although a large percent of their hairy roots may be lost when they are dug from the field (Marshall and Gilman 1998; Percival and Barnes 2004). Because all the soil is removed from $B R$ trees, their shipping and handling costs are lower, resulting in $33 \%$ to $50 \%$ cost reduction when compared to $B \& B$ trees (Trowbridge and Bassuk 2004). The disadvantage of $B R$ trees is that having lost their protective soil cover, roots are more exposed to desiccation (Anella et al. 2008). Numerous studies compared post-transplant response of FG trees moved as $B \& B$ to those moved BR. Findings of some studies have shown higher mortality in BR trees compared to $B \& B$ trees, especially in regions that experience severe heat and drought (Buckstrup 2004; Sather et 
al. 2004; Etemadi et al. 2013), while other studies have suggested that if BR trees transplanted with proper care (roots dipped in a hydrophilic gel immediately after harvesting and wrapped in a plastic bag to keep the roots moisture), no significant difference could be observed between two methods (Buckstrup and Bassuk 2000; Anella et al. 2008; Jack-Scott 2012).

CG trees have become favored over FG trees in many cases for transplanting projects because a much higher proportion of the root system is retained within the root ball, which allows for the trees to be transplanted with an entirely intact and undisturbed root system. Also, less effort is needed for digging CG trees, and they can be successfully planted during a greater portion of the year (Clewell and Lea 1990; Harris and Gilman 1993). However, increased production costs and the formation of circling roots along the outside or bottom of the root ball, which results in poor establishment of CG trees in the landscape, are limiting factors for large-scale use of CG trees (Amoroso et al. 2010).

Intact root density within the root ball of CG trees has resulted in the assumption that CG trees may tolerate transplant stress better than FG trees. However, there is some evidence demonstrating that there are no significant differences in establishment of various production methods. Gilman (1994) states that trees from a variety of production systems perform almost equally well if regularly irrigated. Blessing and Dana (1987) reported that root spread and new root dry weight of FG Chinese juniper (Juniperus chinensis) was slightly greater than CG trees 16 weeks after transplanting, whereas their shoot growth was not statistically different. In a prolonged experiment, Laiche et al. (1983) showed that five years following transplant, height, caliper, and number of roots were not different between CG and BR trees for Carya illinoensis (Wangenh.) K. Koch.

Biostimulant application at planting is also among the methods that have been used to increase post-transplant survival and encourage rapid establishment (Ferrini and Nicese 2002). Humate-based matters (humic acids, humin, fulvic acids) are formed from the biological and chemical degradation of soil organic matter and are very resistant to further biodegradation (Baigorri et al. 2009). Russo and Berlyn (1990) described these biostimulant as "non-nutritional products that may reduce fertilizer use and increase yield and resistance to water and temperature stress."

Humic acids (HAs) are the main active components among humate-based products (Ferrara and Brunetti 2010). These complex materials may contain vitamins (e.g., thiamine) or other organic materials (e.g., seaweed extracts) and have the potential to directly and indirectly affect different cellular mechanisms, including cell respiration, photosynthesis, protein synthesis, enzyme activities, water, and nutrient uptake (Muscolo et al. 1999; Nardi et al. 2002; Chen et al. 2004; Nikbakht et al. 2008; Khattab et al. 2012). Several studies have also shown that HAs stimulate plant growth and yield by hormone-like activities, in particular auxin/cytokinin effects (Ferrara and Brunetti 2010; Trevisan et al. 2010). Hormone-like activity of HAs has been demonstrated to be dose-dependent, with optimal concentrations in the range of $50-300 \mathrm{mg}$ $\mathrm{kg}^{-1}$, but positive effects have also been exerted by lower concentrations (Chen et al. 2004). However, research on the effects of HAs is mostly reported for vegetable and fruit species (Nikbakht et al. 2008; Hagagg et al. 2013; Mustafa and El-Shazly 2013), and little is known about their efficacy on woody species in landscapes (Ferrini et al. 2005)

In most developing countries with arid climates, freshly dug trees and shrubs are usually used for planting projects, such as afforestation. These trees, depending on species, are highly susceptible to death if not irrigated appropriately. Digging trees and holding them in ground or containers for several weeks or months prior to planting (which is commonly known as hardening-off process) help trees adapt to the new site environment and restore their damaged root system (Gilman 2001). However, hardening-off processes will increase expenses associated with digging, handling, and maintenance of trees, which is in contrast with the goals of large-scale planting projects (i.e., speed and minimum unit cost). Considering the key importance of trees and shrubs and their valuable benefits in arid areas, it is crucial to determine the best transplanting method and practice for each species, as well as treatments that improve transplant success. Therefore, the present study was conducted to 1) determine the impact of production method on hardening-off process of oriental thuja (Platycladus orientalis) trees, 2) compare survival and 
growth responses of hardened-off container-grown trees, with those of freshly dug field-grown trees (B\&B or BR), and 3) evaluate the possible effect of $\mathrm{HA}$ as a growth biostimulant, in an arid climate.

\section{MATERIALS AND METHODS}

In the present study, two field experiments using oriental thuja trees were conducted at Isfahan municipality research station located at MahmoudAbad (Isfahan, Iran, latitude $32^{\circ} 47^{\prime} 49^{\prime \prime} \mathrm{N}$, longitude $51^{\circ} 3512 " \mathrm{E}$, altitude $1,584.6 \mathrm{~m}$ ), from March 2010 to October 2012. All trees were obtained from a field nursery for ornamental trees inside the Mahmoud-Abad research station.

According to 20 years of climatic information obtained from Iran Meteorological Organization, the study area was classified as cold-arid, with mean monthly temperature ranging from $3.2^{\circ} \mathrm{C}$ in winter to $30.5^{\circ} \mathrm{C}$ in summer. Mean daily temperature frequently exceeded $40^{\circ} \mathrm{C}$ during summer. Throughout the experimental period, mean annual evaporation and rainfall were $1,923 \mathrm{~mm}$ and $120 \mathrm{~mm}$, respectively. Rainfall was not seasonally well distributed and mostly concentrated in the November to May period.

\section{First Experiment (hardening-off)}

For the first experiment, 48 thuja trees were selected for uniformity (trunk diameter $10 \mathrm{~cm}$ above the soil line, approx. $4.5 \mathrm{~cm}$; height, approx. 200 $\mathrm{cm}$ ) and dug up using a backhoe with root ball width about 10 times the trunk diameter in late March 2010. Three to four days before harvesting, trees were irrigated in order to facilitate the digging operation. Half of the trees were bare rooted; their roots were sprayed with a stream of water and then kept in shade to maintain moisture. The root balls of 24 remaining trees were wrapped in burlap and laced with wire to prevent them from disintegrating. All harvested trees were shipped to the nearby field and potted in bottomless, aboveground woody containers (upper cross section $=100 \mathrm{~cm} \times 100 \mathrm{~cm}$, lower cross section $=$
$70 \mathrm{~cm} \times 70 \mathrm{~cm}$, height $=120 \mathrm{~cm})$ with horizontal slits embedded in the walls to stimulate lateral air pruning and prevent root spiraling. This approach to digging up trees and holding them in the containers prior to transplanting to the main field was considered a hardening-off process.

Containers were placed on the ground at a distance of $1 \mathrm{~m}$ apart. Before planting, roots or root balls of half $\mathrm{BR}$ or $\mathrm{B} \& \mathrm{~B}$ trees were successively sprayed with $300 \mathrm{mg} / \mathrm{L}$ of humic acid solution prepared from leonardite [containing carbon (C), 61.2\%; nitrogen $(\mathrm{N}), 3.13 \mathrm{~g} / \mathrm{kg}$ dry matter; and phosphorus (P), $2.89 \mathrm{~g} / \mathrm{kg}$ dry matter] until complete drench of roots and surrounding soil. Containers were refilled with the same soil type as the trees were produced. The physical and chemical characteristics of the field soil are shown in Table 1. Long wooden stakes were driven into containers soil just outside of the periphery of the root ball in order to support installed trees against prevailing wind at the experimental site.

Newly potted trees were irrigated daily, for four weeks, as long as water percolated into soil and drained from the bottom of containers; then irrigation was reduced to three to four times weekly, depending on the weather, to maintain field-capacity moist conditions. This amount of irrigation water was greater than that used for trees in Isfahan landscape, but it was applied until tree establishment. Throughout the study, weeds were controlled by hand and no supplemental fertilization was applied to the trees.

Four single-tree replications per treatment combinations (two harvesting method $\times$ two humic acid concentrations) were used in each of three blocks arranged in a randomized complete block design $(4 \times 2 \times 2 \times 3=48)$.

Data collection for all trees was performed in late June and again in late October 2010, when the growth rate was greatly diminished. Percent survival at each measuring date was calculated as the total number of survived trees in each year divided by the initial number of trees.

Table 1. The physical and chemical characteristics of the experimental site's soil.

\begin{tabular}{|c|c|c|c|c|c|c|c|}
\hline \multirow[t]{2}{*}{ Soil texture } & \multirow[t]{2}{*}{ Depth $(\mathrm{cm})$} & \multicolumn{3}{|c|}{ Soil particles (\%) } & \multirow[t]{2}{*}{$\mathrm{pH}$} & \multirow[t]{2}{*}{$\mathrm{EC}(\mathrm{dS} / \mathrm{m})$} & \multirow[t]{2}{*}{$\mathrm{K}(\mathrm{ppm})$} \\
\hline & & Clay & Silt & Sand & & & \\
\hline \multirow[t]{2}{*}{ Clay } & $0-30$ & 53 & 26 & 21 & 7.7 & 2.5 & 21.8 \\
\hline & $0-60$ & 48 & 27 & 25 & 7.9 & 2.8 & 18.7 \\
\hline
\end{tabular}


A tree was considered dead if no leaves were present and no green tissue was evident on the trunk. Average shoot growth was calculated by measuring the current-season growth of three randomly selected full-sun terminal shoots on three mid-canopy branches of each tree.

Two visual indices were also developed and measured, called "canopy desiccation" and "canopy color." The first index represents an estimate of extent dieback and leaf desiccation within the canopy. A percentage scale was used for canopy desiccation rating, with $100 \%$ corresponding to a fully leafed-out tree that has no dieback within the canopy. For canopy color index, a rating from 1 to 10 was used. A rating of 10 corresponds to color similar to leaf color of an un-transplanted and unstressed tree. Trunk diameter (measured $10 \mathrm{~cm}$ above the soil surface on the thickest stem, since thuja tend to have several stems) and tree height were recorded for all trees at each measuring time. Then, trunk diameter and height increments were calculated by subtracting June measurements from October measurements.

\section{Second Experiment (landscape plant- ing treatments)}

The second trial was carried out in the same field with the following changes. Twelve $\mathrm{B} \& \mathrm{~B}$ trees grown in the containers during the first year (now referring to $\mathrm{CG}$ trees) were transplanted along with freshly dug field-grown trees (both $B \& B$ and BR). For this end, 24 FG trees of similar size and age to the CG trees were selected from an ornamental tree nursery in Mahmoud-Abad research station and harvested as $\mathrm{BR}$ or $\mathrm{B} \& \mathrm{~B}$ trees with similar practices to the first experiment.

Roots or root balls of half $\mathrm{BR}$ or $\mathrm{B} \& \mathrm{~B}$ trees were treated with $300 \mathrm{mg} / \mathrm{L} \mathrm{HA}$ solution prior to planting. Planting holes were dug with a backhoe to roughly twice the width and the same depth of the root ball and spaced $2 \mathrm{~m}$ within and $3 \mathrm{~m}$ between rows. Burlap and containers were removed from $\mathrm{B} \& \mathrm{~B}$ and $\mathrm{CG}$ trees before planting. After installation, the planting holes were refilled with original, unamended soil, and each tree was individually flood irrigated. Thereafter, Plants were watered as needed throughout the experiment. Weeds were controlled mechanically during the trial. No supplemental fertilization was applied to the trees.
The experiment was a randomized complete block design with three transplant method $x$ two humic acid concentration $\times$ three blocks. There were two trees per treatment combination per block $(3 \times 2 \times 3 \times 2=36)$.

Data regarding post-transplant growth and survival were collected similar to the first year. Measurements were done in late June and again in late October of both 2011 and 2012. Trunk diameter and height increments were calculated by subtracting June measurements from October measurements in each year. By the end of the second year (2012), current-season shoot growth and visual indices (canopy desiccation and canopy color) of three untransplanted trees that had almost equal size of transplanted trees were also measured in order to examine tree establishment. Untransplanted trees were inside the research station and were in a similar situation to transplanted trees in terms of soil and environmental condition.

\section{Data Analysis}

For both experiments, survival data were analyzed using $\chi^{2}$ tests $(P<0.05)$ in SPSS ver. 16.0. Data for other indices were subjected to analysis of variance using SAS ver. 9.1. Mean separation was accomplished with Duncan's multiplerange test at the $5 \%$ level of significance.

\section{RESULTS}

\section{First Experiment \\ Survival}

Results of late June 2010 recordings-four months following potting trees in containers-revealed that production method had a significant impact on tree survival during the hardening-off period (Table 2). B\&B trees (irrespective to HA application) showed $100 \%$ survival, while the overall survival of BR trees reached to $62.5 \%$. HA treatment resulted in about a $17 \%$ increase in survival rate of BR-transplanted trees.

By the end of October 2010, production method and biostimulant treatment each had a significant effect on tree survival, as did the interaction between them (Table 2). The overall survival of $\mathrm{B} \& \mathrm{~B}$ trees (regardless of $\mathrm{HA}$ application) remained $100 \%$, whereas it declined to $50 \%$ in BR trees. Also, while no further mortality 
was observed in HA-treated BR trees, their non-treated counterparts continued to die, leaving only $33.3 \%$ of transplanted trees alive.

\section{Growth}

By late June 2010, only shoot extension was affected by production method (Table 3 ). Shoot growth of $B \& B$ trees was 1.7 times greater than their BR counterparts. No significant differences were observed between B\&B and BR trees in terms of canopy desiccation and canopy color rates. HA-treated trees had somewhat better growth than non-treated trees, although observed differences were not statistically significant. Interaction between two treatments was significant only for shoot extension. B\&B trees treated with $\mathrm{HA}$ showed maximum shoot growth (with $7.4 \mathrm{~cm}$ ), while the least amount was observed for non-HA treated BR trees with $2.75 \mathrm{~cm}$ (data not shown).

By the end of October 2010, the impact of production method became more pronounced for different growth parameters. Canopy desiccation index for B\&B trees was approximately 2.3 times lower than BR trees (Table 3). Also, the canopy color rate of these trees was 1.3 times higher as compared to $\mathrm{BR}$ trees. A noticeable point was that irrespective to treatments, shoot extension was greater than late-June. However, $B \& B$ trees still had greater shoot growth than BR trees $(11.3 \mathrm{~cm}$ versus $8 \mathrm{~cm})$. By recording the trees' trunk diameter and height during June to October 2010, it was revealed that harvesting method had significant impact on growth rates of aforementioned indices. Trunk diameters and height increases of $\mathrm{B} \& \mathrm{~B}$ trees were 1.3 and 1.2 times greater than BR trees, respectively.

HA application had no substantial impact on the trees' canopy desiccation, canopy color, or shoot growth. Also, HA-treated and nontreated trees had almost the same growth rates for trunk diameter and height increases. Significant interaction between two treatments was observed for canopy color rate (Table 3). Non-HA-treated $B \& B$ trees had greatest canopy color (with a rate of 5.6), while the least amount was observed for non-HA-treated BR trees with a rate of 3.5 (data not shown).

Table 2. Effects of production method and humic-acid application on percent survival of oriental thuja (Platycladus orientalis) trees during hardening-off period.

\begin{tabular}{|c|c|c|c|c|c|c|c|}
\hline & & \multicolumn{3}{|c|}{$\begin{array}{l}\text { Late June } \\
\text { Production method }\end{array}$} & \multicolumn{3}{|c|}{$\begin{array}{l}\text { Late October } \\
\text { Production method }\end{array}$} \\
\hline & & $\mathrm{B} \& \mathrm{~B}$ & $\mathrm{BR}$ & Overall & $B \& B$ & BR & Overall \\
\hline Biostimulant & $\begin{array}{l}\text { Control } \\
\text { Humic acid } \\
\text { Overall }\end{array}$ & $\begin{array}{l}100\left(12^{z}\right) \\
100(12) \\
100 A \\
\end{array}$ & $\begin{array}{l}50(6) \\
66.7(8) \\
58.3 \mathrm{~B} \\
\end{array}$ & $\begin{array}{l}75 \mathrm{~A}^{\mathrm{y}} \\
83.3 \mathrm{~A}\end{array}$ & $\begin{array}{l}100(12) \\
100(12) \\
100 \mathrm{~A} \\
\end{array}$ & $\begin{array}{l}33.3(4) \\
66.7(8) \\
50 \mathrm{~B}\end{array}$ & $\begin{array}{l}66.7 \mathrm{~A} \\
83.3 \mathrm{~A}\end{array}$ \\
\hline$P$-value & $\begin{array}{l}\text { Production method } \\
\text { Biostimulant } \\
\text { Production } \times \text { Biostimulant }\end{array}$ & $\begin{array}{l}0.03 \\
0.90 \\
0.03\end{array}$ & $\begin{array}{l}0.01 \\
0.60 \\
<0.01\end{array}$ & & & & \\
\hline
\end{tabular}

${ }^{\mathrm{z}}$ Percent survival is followed in parentheses by number of survived trees. The total number of trees for each treatment is 12.

y Treatment overall means within each row or column followed by the same letter are not significantly different according to $\chi^{2}$ test $(P \leq 0.05)$.

Table 3. Effects of production method and humic acid application on canopy desiccation (CD), canopy color (CC), shoot extension (SE), height increase (HI), and trunk diameter increase (DI) of oriental thuja (Platycladus orientalis) trees during hardening-off period.

\begin{tabular}{|c|c|c|c|c|c|c|c|c|c|}
\hline & & \multicolumn{3}{|c|}{ Late June } & \multicolumn{5}{|c|}{ Late October } \\
\hline & & $\mathrm{CD}$ & $\mathrm{CC}$ & SE & $\mathrm{CD}$ & $\mathrm{CC}$ & SE & $\mathrm{HI}^{\mathrm{z}}$ & DI \\
\hline \multirow{2}{*}{$\begin{array}{l}\text { Production } \\
\text { method }\end{array}$} & $\mathrm{B} \& \mathrm{~B}$ & $41.8 \mathrm{a}^{\mathrm{y}}$ & $5.3 \mathrm{a}$ & $7.1 \mathrm{a}$ & $21.1 \mathrm{~b}$ & $5.2 \mathrm{a}$ & $11.3 \mathrm{a}$ & $7.7 \mathrm{a}$ & $1 \mathrm{a}$ \\
\hline & $\mathrm{BR}$ & $42.1 \mathrm{a}$ & $5 \mathrm{a}$ & $4.2 \mathrm{~b}$ & $47.9 \mathrm{a}$ & $4 \mathrm{~b}$ & $8 \mathrm{~b}$ & $6.4 \mathrm{~b}$ & $0.77 \mathrm{~b}$ \\
\hline \multirow[t]{2}{*}{ Biostimulant } & Control & $38.7 \mathrm{a}$ & $5.1 \mathrm{a}$ & $5.7 \mathrm{a}$ & $25.7 \mathrm{a}$ & $4.8 \mathrm{a}$ & $9 \mathrm{a}$ & $7.3 \mathrm{a}$ & $1 \mathrm{a}$ \\
\hline & Humic acid & $44.2 \mathrm{a}$ & $5.3 \mathrm{a}$ & $6.8 \mathrm{a}$ & $33.4 \mathrm{a}$ & $4.8 \mathrm{a}$ & $11.8 \mathrm{a}$ & $7.2 \mathrm{a}$ & $0.9 \mathrm{a}$ \\
\hline \multirow[t]{3}{*}{$P$-value } & Production method & 0.96 & 0.54 & $<0.01$ & $<0.01$ & 0.01 & 0.15 & 0.03 & 0.01 \\
\hline & Biostimulant & 0.5 & 0.46 & 0.13 & 0.64 & 0.79 & 0.2 & 0.87 & 0.33 \\
\hline & Production $\times$ Biostimulant & 0.09 & 0.37 & $<0.01$ & 0.21 & 0.02 & 0.56 & 0.44 & 0.27 \\
\hline
\end{tabular}

${ }^{\mathrm{z}}$ Height increase and trunk diameter increase were calculated by subtracting June measurements from October measurements.

y Treatment means within column in each treatment followed by the same letter are not significantly different according to Duncan's multiple-range test $(P \leq 0.05)$. 


\section{Second Experiment}

For the second experiment, measurements were done in late June and again in late October of both 2011 and 2012, however a similar trend was observed in changes of different parameters each year. Therefore, only late October data of each year was reported to eliminate redundancy.

\section{Survival}

By the end of the first year following transplanting, the survival rate presented significant differences among the trees of three transplanting methods (Table 4). Hardened-off trees transplanted from containers (CG) had significantly greater survival rate $(100 \%)$ than $\mathrm{B} \& \mathrm{~B}(83.3 \%)$ and $\mathrm{BR}(41.7 \%)$ trees. The difference in overall survival rate of HA treated and control trees was found to be negligible. Transplanting method and biostimulant application interacted significantly, although no constant trend could be observed. While HA-treatment improved survival rate of BR trees, it resulted in decreased vitality of B\&B trees. During the second year, no further mortality was observed in trees of all treatments, and survival rates remained at the same value as the late October 2011 records.

\section{Post-transplant growth}

Based on results from October 2011 measurements, transplanting method had a significant effect on all growth parameters of oriental thuja trees (Table 5). The maximum desiccation percentage was observed for BR trees (53.8\%), which was 8.5 and 3.6 times greater than CG and $\mathrm{B} \& \mathrm{~B}$ trees, respectively. Accordingly, other growth indices were greater for $C G$ trees, followed by $B \& B$ and $B R$ trees, respectively.
Humic acid application affected growth of transplanted trees during the first year. HAtreated trees (across production methods) exhibited relatively better visual performance compared to their non-treated counterparts, as they had higher canopy color rate and lower desiccation within canopy. HA-treated trees had also greater shoot extension than control trees. Based on the results, the relationships for $\mathrm{HA} \times \mathrm{CG} / \mathrm{B} \& \mathrm{~B}$ were not rational and clear trends were hard to discern. For BR, however, HA application substantially improved all growth parameters. Canopy desiccation rate of HA-treated BR trees was 2.9 times lower, and their canopy color and shoot extension were 2.4 and 2.8 times greater than non-treated BR trees (data not shown).

Similar to the first year, BR trees had substantially lower performance than $C G$ and $B \& B$ trees in all measured parameters by the end of second year, except for shoot extension and height increase, which were statistically equal for trees of all three methods (Table 5). Furthermore, no significant differences were observed between growth responses of $C G$ and $B \& B$ trees during this year.

Growth responses of HA-treated trees were slightly better than non-HA-treated trees by late October 2012. However, only canopy color rate was statistically significant (1.25 times greater).

Data for biostimulant $\times$ transplanting method also indicated that HA application resulted in 2.6 times lower canopy desiccation and 2.5 and 1.85 times higher, canopy color and shoot extension, respectively, in $\mathrm{BR}$ trees as compared to non-HA treated trees (data not shown).

Table 4. Effects of production method and humic acid application on percent survival of oriental thuja trees (Platycladus orientalis) in the first and second years following transplanting.

\begin{tabular}{|c|c|c|c|c|c|c|c|c|c|}
\hline & & \multicolumn{4}{|c|}{$\begin{array}{l}\text { First year } \\
\text { Production method }\end{array}$} & \multicolumn{4}{|c|}{$\begin{array}{l}\text { Second year } \\
\text { Production method }\end{array}$} \\
\hline & & CG & $\mathrm{B} \& \mathrm{~B}$ & $\mathrm{BR}$ & Overall & CG & $\mathrm{B} \& \mathrm{~B}$ & $\mathrm{BR}$ & Overall \\
\hline Biostimulant & $\begin{array}{l}\text { Control } \\
\text { Humic acid } \\
\text { Overall }\end{array}$ & $\begin{array}{l}100\left(6^{z}\right) \\
100(6) \\
100 A\end{array}$ & $\begin{array}{l}100(6) \\
66.7(4) \\
83.3 \mathrm{~B}\end{array}$ & $\begin{array}{l}33.3(2) \\
50(3) \\
41.7 \mathrm{C}\end{array}$ & $\begin{array}{l}77.8 \mathrm{~A}^{\mathrm{y}} \\
72.2 \mathrm{~A}\end{array}$ & $\begin{array}{l}100(6) \\
100(6) \\
100 \mathrm{~A}\end{array}$ & $\begin{array}{l}100(6) \\
66.7(4) \\
83.3 \mathrm{~B}\end{array}$ & $\begin{array}{l}33.3(2) \\
50(3) \\
41.7 \mathrm{C}\end{array}$ & $\begin{array}{l}77.8 \mathrm{~A} \\
72.2 \mathrm{~A}\end{array}$ \\
\hline$P$-value & $\begin{array}{l}\text { Production method } \\
\text { Biostimulant } \\
\text { Production } \times \text { Biostimulant }\end{array}$ & & & & $\begin{array}{l}0.01 \\
0.7 \\
<0.01\end{array}$ & & & & $\begin{array}{l}0.01 \\
0.7 \\
<0.01\end{array}$ \\
\hline
\end{tabular}

${ }^{\mathrm{z}}$ Percent survival is followed in parentheses by number of survived trees. The total number of trees for each treatment is 12.

y Treatment overall means within each row or column followed by the same letter are not significantly different according to $\chi^{2}$ test $(P \leq 0.05)$. 
Table 5. Effects of production method and humic acid application on canopy desiccation (CD), canopy color (CC), shoot extension (SE), height increase (HI), and trunk diameter increase (DI) of oriental thuja (Platycladus orientalis) trees in the first and second years following transplanting.

\begin{tabular}{|c|c|c|c|c|c|c|c|c|c|c|c|}
\hline & & \multicolumn{5}{|c|}{ First year } & \multicolumn{5}{|c|}{ Second year } \\
\hline & & $\mathrm{CD}$ & $\mathrm{CC}$ & SE & $\mathrm{HI}$ & DI & $\mathrm{CD}$ & $\mathrm{CC}$ & $\mathrm{SE}$ & $\mathrm{HI}$ & DI \\
\hline $\begin{array}{l}\text { Production } \\
\text { method }\end{array}$ & $\begin{array}{l}\mathrm{CG} \\
\mathrm{B} \& \mathrm{~B} \\
\mathrm{BR}\end{array}$ & $\begin{array}{l}6.2 \mathrm{~b}^{\mathrm{z}} \\
15.8 \mathrm{~b} \\
53.7 \mathrm{a}\end{array}$ & $\begin{array}{l}7.7 \mathrm{a} \\
7.6 \mathrm{a} \\
5.4 \mathrm{~b}\end{array}$ & $\begin{array}{l}24.2 \mathrm{a} \\
17.3 \mathrm{~b} \\
11.5 \mathrm{c}\end{array}$ & $\begin{array}{l}22.7 \mathrm{a} \\
15.5 \mathrm{~b} \\
7.3 \mathrm{c}\end{array}$ & $\begin{array}{l}2 \mathrm{a} \\
1.2 \mathrm{~b} \\
0.8 \mathrm{c}\end{array}$ & $\begin{array}{l}2.9 \mathrm{~b} \\
9.75 \mathrm{~b} \\
54.1 \mathrm{a}\end{array}$ & $\begin{array}{l}8.25 \mathrm{a} \\
7.9 \mathrm{a} \\
5.5 \mathrm{~b}\end{array}$ & $\begin{array}{l}13.4 \mathrm{a} \\
11.8 \mathrm{a} \\
10.0 \mathrm{a}\end{array}$ & $\begin{array}{l}26 \mathrm{a} \\
22 \mathrm{a} \\
19.8 \mathrm{a}\end{array}$ & $\begin{array}{l}1.01 \mathrm{a} \\
1.2 \mathrm{a} \\
0.5 \mathrm{~b}\end{array}$ \\
\hline Biostimulant & $\begin{array}{l}\mathrm{C} \\
\mathrm{HA} \\
\end{array}$ & $\begin{array}{l}31 \mathrm{a} \\
19.6 \mathrm{a} \\
\end{array}$ & $\begin{array}{l}6.2 \mathrm{a} \\
7.6 \mathrm{a} \\
\end{array}$ & $\begin{array}{l}15.2 \mathrm{~b} \\
20.2 \mathrm{a} \\
\end{array}$ & $\begin{array}{l}12.6 \mathrm{~b} \\
18.6 \mathrm{a} \\
\end{array}$ & $\begin{array}{l}1.3 \mathrm{a} \\
1.5 \mathrm{a}\end{array}$ & $\begin{array}{l}27.8 \mathrm{a} \\
16.6 \mathrm{a} \\
\end{array}$ & $\begin{array}{l}6.4 \mathrm{~b} \\
8.0 \mathrm{a}\end{array}$ & $\begin{array}{l}10.6 \mathrm{a} \\
12.8 \mathrm{a} \\
\end{array}$ & $\begin{array}{l}19.5 \mathrm{a} \\
26.5 \mathrm{a} \\
\end{array}$ & $\begin{array}{l}0.8 \mathrm{a} \\
0.9 \mathrm{a}\end{array}$ \\
\hline$P$-value & $\begin{array}{l}\text { Production method } \\
\text { Biostimulant } \\
\text { Production } \times \text { Biostimulant }\end{array}$ & $\begin{array}{l}0.01 \\
0.20 \\
0.07\end{array}$ & $\begin{array}{l}0.05 \\
0.06 \\
0.02\end{array}$ & $\begin{array}{l}<0.01 \\
0.01 \\
0.05\end{array}$ & $\begin{array}{l}<0.01 \\
0.04 \\
0.18\end{array}$ & $\begin{array}{l}<0.01 \\
0.36 \\
0.27\end{array}$ & $\begin{array}{l}0.03 \\
0.18 \\
0.08\end{array}$ & $\begin{array}{l}0.02 \\
0.03 \\
0.01\end{array}$ & $\begin{array}{l}0.23 \\
0.11 \\
0.28\end{array}$ & $\begin{array}{l}0.30 \\
0.12 \\
0.35\end{array}$ & $\begin{array}{l}0.02 \\
0.32 \\
0.39\end{array}$ \\
\hline
\end{tabular}

${ }^{\mathrm{z}}$ Treatment means within column in each treatment followed by the same letter are not significantly different according to Duncan's multiple-range test $(P \leq 0.05)$.

\section{Tree establishment}

In order to assess the establishment of transplanted trees, their current-season shoot growth, as well as their visual indices at the end of the second year (i.e., 2012), were compared to untransplanted trees. No significant difference was observed between untransplanted and CG trees in terms of canopy desiccation (Table 6). $B \& B$ trees also had low desiccation, although it was statistically higher than desiccation percentage of $\mathrm{CG}$ and untransplanted trees. Furthermore, canopy color rates of $C G$ and $B \& B$ trees equaled to color rate of untransplanted trees by the end of the experiment. BR trees, however, had still statistically greater canopy desiccation (54.1\% versus $0 \%$ ) and lower color rate (5.5 versus 8.4) than that of untransplanted trees, suggesting that BR transplanting method for thuja species may be more stressful. Based on results from current-season shoot growth, shoot extension was the most on CG trees at $13.4 \mathrm{~cm}$ followed by untransplanted, B\&B, and BR trees at 12, 11.7, and $10 \mathrm{~cm}$, respectively, although the observed differences were not statistically significant.

Table 6. Comparing canopy desiccation (CD), canopy color (CC), and shoot extension (SE) of transplanted oriental thuja (Platycladus orientalis) trees from different production methods to un-transplanted (UT) trees.

\begin{tabular}{llll}
\hline $\begin{array}{l}\text { Transplanting } \\
\text { method }\end{array}$ & $\begin{array}{l}\text { Canopy } \\
\text { desiccation }\end{array}$ & $\begin{array}{l}\text { Canopy } \\
\text { color }\end{array}$ & $\begin{array}{l}\text { Shoot } \\
\text { extension }\end{array}$ \\
\hline UT & $0 \mathrm{c}^{\mathrm{z}}$ & $8.4 \mathrm{a}$ & $12 \mathrm{a}$ \\
$\mathrm{CG}$ & $2.9 \mathrm{c}$ & $8.2 \mathrm{a}$ & $13.4 \mathrm{a}$ \\
$\mathrm{B} \& \mathrm{~B}$ & $9.7 \mathrm{bc}$ & $7.9 \mathrm{a}$ & $11.8 \mathrm{a}$ \\
$\mathrm{BR}$ & $54.1 \mathrm{a}$ & $5.5 \mathrm{~b}$ & $10 \mathrm{a}$ \\
$P$-value & $<0.01$ & 0.01 & 0.36 \\
\hline
\end{tabular}

${ }^{\mathrm{z}}$ Treatment means within each column followed by the same letter are not significantly different according to Duncan's multiple-range test $(P \leq 0.05)$.

\section{DISCUSSION}

\section{Production Method}

In the first experiment of the present study, researchers harvested oriental thuja trees as BR (less expensive method) or B\&B (more expensive method) and hardened-off the trees in containers for one year before planting into the main field, in order to evaluated the impact of harvesting technique on growth and survival during hardening-off period.

Effect of harvesting technique was evident from the early months following transplanting. While trees potted in containers as $B \& B$ trees had no mortality, only half of their BR counterparts survived by the end of the trial period, and their growth responses were significantly lower than $B \& B$ trees. These results suggest that BR transplanting of oriental thuja trees may be more stressful, and BR trees would not be able to successfully withstand transplant shock. Apart from the different climate conditions, soil type, and planting practices, species type is a decisive factor in response to transplanting method. Findings of some studies directly comparing BR and $B \& B$ trees have shown higher mortality in bare-rooted trees. Survival rates of transplanted evergreen species eldarica pine (Pinus eldarica Medw.), as well as two deciduous trees, white mulberry (Morus alba L.) and smoothleaf elm (Ulmus carpinifolia Gled.), have been reported to be more for $\mathrm{B} \& \mathrm{~B}$ trees than their similar-sized $\mathrm{BR}$ trees (Etemadi et al. 2013). In contrast to these reports, Anella et al. (2008) found no significant difference in mortality of B\&B and BR stocks of 
Platanus $\times$ acerifolia, Acer $\times$ freemanii, and Taxodium distichum. Similar results on 10 urban street species were also reported by Jack-Scott (2012).

$\mathrm{B} \& \mathrm{~B}$ trees potted in containers (irrespective to HA treatment) had no mortality during the hardening-off period, and grew better than BR trees. Therefore, these trees (termed as CG trees) were used in the second experiment in order to compare their post-transplant growth and survival with freshly dug FG trees (B\&B or BR). It is notable that no significant root defects were detected in CG trees, whereas a substantial amount of fine roots were produced. This is probably due to the bottomless containers with slits embedded in the walls used in this study, which can stimulate lateral air pruning and reduce the incidence of deformed roots. Several studies have demonstrated that container type can affect the root-system architecture and long-term problems on plant growth (Marshall and Gilman 1998; Amoroso et al. 2010; Gilman et al. 2010). Comparison between hardened-off CG trees and FG trees showed CG trees had greater percent survival and growth responses by the end of the first year following transplanting. This can be attributed to the less stress of hardened-off CG trees, resulting from their adaptation to the planting site environment and new root regeneration. It has been shown that container trees are better able to meet the transpirational needs of the plant immediately after transplanting due to the production of many fine roots along the outside of the root ball that can rapidly penetrate into the surrounding soil and absorb water from it (Harris and Gilman 1993).

In confirming the results of the first experiment, BR trees suffered from transplant stress more than other methods, suggesting the susceptibility of oriental thuja to the bare-rooted transplanting method.

In a similar study, Mexal et al. (2002) compared post-transplant growth and survival of containerized Spanish cedar (Cedrela odorata L.) to BR seedlings. Containerized seedlings had $82 \%$ survival (compared to $10 \%$ for BR) and nearly twice the growth after 28 months. After 57 months, all the BR seedlings had died, while $50 \%$ of the containerized seedlings survived. In another study, Harris and Gilman (1993) showed that freshly dug fieldgrown B\&B East Palatka holly (Ilex $\times$ attenuata 'East Palatka') trees were more stressed and more likely to die than trees planted from plastic con- tainers if they were not regularly irrigated after transplanting due to the sudden loss of roots. However, with regular irrigation, laurel oak (Quercus laurifolia) and East Palatka holly trees (Gilman and Beeson 1996) and live oak (Gilman 2001), from either $B \& B$ or container production method, experienced similar post-transplant water stress.

By the end of the second year of the current study, the significant differences observed between $B \& B$ and $C G$ trees disappeared for all measured variables. It was also found in some previous studies that first year effects of transplanting method may not persist in the following years (Vanstone and Ronald 1981; Buckstrup and Bassuk 2000; Etemadi et al. 2013). This observation is of significant importance, as it shows freshly dug oriental thuja trees can be successfully transplanted using the prevalent $\mathrm{B} \& \mathrm{~B}$ method without the hardening-off process, which requires more time, labor, and expense.

\section{Humic Acid}

Based on the results of the first and second experiments, HA application (across production methods) was not able to substantially improve growth and vitality of transplanted trees, except for BR trees. HA-treated BR trees possessed relatively higher survival percentage and greater canopy color rate, shoot extension, and lower canopy desiccation compared to non HA-treated BR trees. These observations may be related to the supposed influence of HAs on stimulating drought tolerance (Russo and Berlyn 1990; Farahat et al. 2012) and increase in the synthesis of the chlorophyll and photosynthesis rate that consequently promote plant growth (Chen et al. 2004; Nikbakht et al. 2008; Ferrara and Brunetti 2010). An increase in absorption of mineral nutrients and the possible hormone-like activity of the HAs (i.e., auxin-, gibberellin-, and cytokininlike activity) can also promote growth of BR trees and ameliorate the harmful effects of water stress (Mustafa and El-Shazly 2013). It has to be pointed out that despite better performance of HA-treated $\mathrm{BR}$ trees, this procedure would not be advisable for transplanting oriental thuja species due to the high mortality rate of BR trees (regardless of HA treatment) compared to the other transplanting methods.

No significant differences were found between the HA-treated trees from $B \& B$ and $C G$ methods and their control counterparts. B\&B and CG trees 
generally lose fewer roots and suffer less from transplant shock compared to BR trees. Therefore, the beneficial impact of HA on drought tolerance and nutrient uptake of $B \& B$ and $C G$ trees may be less profound than on BR trees. Ferrini et al. (2005) reported that B\&B English oaks treated with leonardite were rarely better than control trees regarding shoot extension, leaf area, and chlorophyll content. In another study, the effect of four different types of humate biostimulants was evaluated on CG Turkish hazelnut (Corylus colurna L.). No treatment experiment showed improved growth compared to untreated trees. Similar results were obtained for some container-grown landscape trees (Laiche 1991).

\section{Tree Establishment}

Several criteria of establishment following transplanting have been proposed, including the time required to reestablish the original crown:rootspread ratio, or the time needed to resume the pretransplant trunk growth or current-season shoot growth (Watson et al. 1986; Starbuck et al. 2005; Ross 2008). In the present study, tree establishment was evaluated by comparing current-season shoot growth and visual indices of transplanted trees to growth of untransplanted trees. By the end of the second year after transplanting, current-season shoot growth of all transplanted trees were statistically equal to the growth of same-sized untransplanted trees, although shoot growth of BR trees was still lower compared to other methods. Also, no significant differences were observed between canopy color and canopy desiccation rates of $B \& B$ and CG trees, while both indices were substantially lower for BR trees. Therefore, it seems that $\mathrm{B} \& \mathrm{~B}$ - and CG-transplanted trees were almost established during the two years, whereas the BR trees required more time to be fully established.

Overall, the results of this study suggest that transplanting method has a strong influence on survival, growth, and establishment of oriental thuja trees. BR trees were not able to successfully tolerate the hardening-off period and did not show proper growth and survival following transplanting. The hardened-off CG trees performed better than freshly dug FG trees in terms of growth and percentage of vitality by the end of the first year. However, this initial advantage disappeared gradually thereafter. The practical significance of this result is that the $\mathrm{B} \& \mathrm{~B}$ transplanting method of oriental thuja would be both reliable and less expensive than the CG method for large-scale planting projects. This would be important particularly in arid climates with restricted water resources, as the hardening-off process of trees (CG or FG) needs more time and subsequently a greater water supply. On the other hand, results of this study do not support utility of humic acid as an aid to posttransplant establishment of oriental thuja trees.

Acknowledgments. The authors would like to thank the Parks and Landscape Organization of Isfahan Municipality for financial support of this research.

\section{LITERATURE CITED}

Amoroso, G., P. Frangi, and R. Piatti. 2010. Effect of container design on plant growth and root deformation of little leaf linden and field elm. HortScience 45:1824-1829.

Anella, L., T.C. Hennessey, and E.M. Lorenzi. 2008. Growth of balled-and-burlapped versus bare-root trees in Oklahoma, U.S. Arboriculture \& Urban Forestry 34:200-203.

Apostol, K.G., F. Douglass, D.F. Jacobs, and R.K. Dumroese. 2009. Root desiccation and drought stress responses of bare root Quercus rubra seedlings treated with a hydrophilic polymer root dip. Plant Soil 315:229-240.

Baigorri, R., M. Fuentes, G. González-Gaitano, J.M. García-Mina, G. Almendros, and F.J. González-Vila. 2009. Complementary multi-analytical approach to study the distinctive structural features of the main humic fractions in solution: Gray humic acid, brown humic acid, and fulvic acid. Journal of Agricultural and Food Chemistry 57:3266-72.

Blessing, S.C., and M.N. Dana. 1987. Post-transplant root system expansion in Juniperus chinensis L. as influenced by production system, mechanical root disruption, and soil type. Journal of Environmental Horticulture 5:155-158.

Buckstrup, M. 2004. Secrets laid bare. American Nurseryman 200:28-30

Buckstrup, M.J., and N.L. Bassuk. 2000. Transplanting success of balled and burlapped versus bare-root trees in the urban landscape. Arboriculture \& Urban Forestry 26:298-308.

Chen, Y., M. De Nobili, and T. Aviad. 2004. Stimulatory effects of humic substances on plant growth. pp. 103-129. In: F. Magdoff and R.R. Weil (Eds.). Soil organic matter in sustainable agriculture. CRC Press, New York, New York, U.S.

Clewell, A.F., and R. Lea. 1990. Creation and restoration of forested wetland vegetation in the Southeastern United States. pp. 195232. In: J.A. Kusler, and M.A. Kentula (Eds). Wetland creation and restoration: The status of the science. Island Press, Washington, D.C., U.S.

Etemadi, N., R. Mohammadi Nezhad, N. Zamani, and M.M. Majidi. 2013. Effect of transplanting date and harvest method on growth and survival of three urban tree species in an arid climate. Arboriculture \& Urban Forestry 39:211-217

Farahat, M.M., A.A.M Mazhar, and M.H. Mahgou. 2012. Response of Khaya senegalensis seedlings to irrigation intervals and foliar application of humic acid. Journal of Horticultural Science and Ornamental Plants 4:292-298. 
Ferrara, G., and G. Brunetti. 2010. Effects of the times of application of a soil humic acid on berry quality of table grape (Vitis vinifera L.) cv Italia. Spanish Journal of Agricultural Research $8: 817-822$.

Ferrini, F., A. Giuntoli, F.P. Nicese, S. Pellegrini, and N. Vignozzi. 2005. Effect of fertilization and backfill amendments on soil characteristics, growth, and leaf gas exchange of English oak (Quercus robur 1.). Journal of Arboriculture 31:182-190.

Ferrini, F., and F.P. Nicese. 2002. Response of English oak Quercus robur L. trees to biostimulants application in the urban environment. Journal of Arboriculture 28:70-75.

Gilman, E.F. 1994. Establishing trees in the landscape. pp. 69-77. In: D. Neely and G.W. Watson (Eds.). The Landscape Below Ground: Proceedings of an International Workshop on Tree Root Development in Urban Soils. International Society of Arboriculture, Champaign, Illinois, U.S. 222 pp.

Gilman, E.F. 2001. Effect of nursery production method, irrigation, and inoculation with mycorrhizae-forming fungi on establishment of Quercus virginiana. Journal of Arboriculture 27:30-39.

Gilman, E.F., and R.C. Beeson. 1996. Production method affects tree establishment in the landscape. Journal of Environmental Horticulture 14:81-87.

Gilman, E.F., C. Harchick, and M. Pazm. 2010. Effect of container type on root form and growth of red maple. Journal of Environmental Horticulture 28:1-7.

Hagagg, L.F., E.A.E. Genaidy, M.F.M. Shahin, N.S. Mustafa, and H.S.A. Hassan. 2013. Effect of number of applications of humic acid on fruit quality and quantity of Picual olives under North Sinai condition. Journal of Applied Science and Research 9:1092-1096.

Harris, J.R., and E.F. Gilman. 1993. Production method affects growth and post-transplant establishment of 'East Palatka' holly. Journal of American Society for Horticultural Science 118:194-200.

Jack-Scott,E. 2012. Survival and growth factors affecting communityplanted urban street trees. CATE. 4:1-14. <http://digitalcommons.lmu.edu/cate/vol4/iss1/10>

Khattab, M.M., A.E. Shaban, A.H. El-Shrief, and A.S. El-Deen Mohamed. 2012. Effect of humic acid and amino acid on pomegranate trees under deficit irrigation. I: Growth, flowering, and fruiting. Journal of Horticultural Science and Ornamental Plants 4:253-259.

Laiche, A.J. 1991. Evaluation of humic acid and slow release fertilizers on container-grown landscape plants. Mississippi Agriculture and Forestry Experiment Station bulletin 16:1-3.

Laiche, A.J., W.W. Kilby, and J.P. Overcash. 1983. Root and shoot growth of field- and container-grown pecan nursery trees five years after transplanting. HortScience 18:328-329.

Marshall, M.D., and E.F. Gilman. 1998. Effects of nursery container type on root growth and landscape establishment of Acer rubrum L. Journal of Environmental Horticulture 15:55-59.

Mexal, J.G, R.A. Cuevas Rangel, P. Negreros-Castillo, and C. Paraguirre Lezama. 2002. Nursery production practices affect survival and growth of tropical hardwoods in Quintana Roo, Mexico. Forest Ecology Management 168:125-133.

Muscolo, A., F. Bovalo, F. Gionfriddo, and S. Nardi. 1999. Earthworm humic matter produces auxin-like effects on Daucus carota cell growth and nitrate metabolism. Soil Biology and Biochemistry 31:1303-1311.
Mustafa, N.S., and S.M. El-Shazly. 2013.Impact of some biostimulant substances on growth parameters of Washington Navel orange trees. Middle East Journal of Applied Science 3:156-160.

Nardi, S., D. Pizzeghello, A. Muscolo, and A. Vianello. 2002. Physiological effects of humic substances in plant growth. Soil Biology and Biochemistry 34:1527-1536.

Nikbakht, A., M. Kafi, A. Luo, M. Babalar, Y.P. Xia., and N. Etemadi. 2008. Effect of humic acid on plant growth, nutrient uptake, and postharvest life of gerbera. Journal of Plant Nutrition 31:2155-2167

Percival, G.C., and S. Barnes. 2004. Auxins and water-retaining polymer root dips affect survival and growth of newly transplanted bare-rooted European beech and silver birch. Journal of Environmental Horticulture 22:183-188.

Ross, M. 2008. The influence of initial tree size on growth, canopy development and physiology in urban environment. Msc thesis. University of Michigan, U.S. 110 pp.

Russo, R.O., and G.P. Berlyn. 1990. The use of organic biostimulants to help low input sustainable agriculture. Journal of Sustainable Agriculture 1:19-42.

Sather, I., E. Macie, and D.R. Hartel. 2004. Urban forestry manual - Benefits and costs of the urban forest. USDA Forest Service, Southern Center for Urban Forest Research and Information. Athens, Georgia, U.S. 377 pp.

Starbuck, C., D.K. Struve, and H. Mathers. 2005. Bare root and balled-and-burlapped red oak and green ash can be summer transplanted using the Missouri gravel bed system. HortTechnology 15:122-127.

Trevisan, S., O. Francioso, S. Quaggiotti. and S. Nardi. 2010. Humic substances biological activity at the plant-soil interface from environmental aspects to molecular factors. Plant Signal Behavior 5:635-643.

Trowbridge, P.J., and N.L. Bassuk. 2004. Trees in the Urban Landscape. Wiley, Hoboken, New Jersey, U.S. 232 pp.

Vanstone, D.E., and W.G. Ronald. 1981. Comparison of bare root versus tree spade transplanting of boulevard trees. Arboriculture \& Urban Forestry 7:271-274.

Watson, G.W., E.B. Himelick, and E.T. Smiley. 1986. Twig growth of eight species of shade trees following transplanting. Journal of Arboriculture 12:241-245.

Nematollah Etemadi (corresponding author)

Department of Horticultural Science

College of Agriculture

Isfahan University of Technology, 84156-83111

Isfahan, Iran

etemadin@cc.iut.ac.ir

Phone: 00983113913416

Fax: 00983113913321

Rezvan Mohammadi Nezhad

Department of Horticultural Science

College of Agriculture

Isfahan University of Technology, 84156-83111

Isfahan, Iran

r.mohammadinezhad@ag.iut.ac.ir 
Résumé. La rareté des données concernant les conditions appropriées pour la transplantation d'arbres en climat aride est une cause majeure de l'échec de la plupart des projets de transplantation. Cette étude a évalué l'efficacité de différentes méthodes de transplantation ainsi que l'application de biostimulants sur la survie et la croissance de l'espèce polyvalente qu'est le thuya de Chine (Platycladus orientalis). Dans la première expérience, les arbres ont été récoltés à racines nues $(\mathrm{RN})$ ou en motte et endurcis en contenants pendant un an avant leur transplantation. Dans la deuxième expérience, la performance post-transplantation d'arbres endurcis en contenants a été comparée à des arbres $\mathrm{RN}$ et en motte fraîchement excavés. Lors des deux expériences, la moitié des arbres furent traités avec $300 \mathrm{mg} / \mathrm{L}$ d'acide humique. Contrairement aux arbres en motte, les arbres à racines nues n'ont pas réussi à tolérer le processus d’endurcissement. Au cours de la première année suivant la transplantation sur des sites paysagers, les arbres endurcis ont montré un taux de survie de $100 \%$ et ont témoigné d'une augmentation significative pour tous les paramètres mesurés par rapport aux arbres $\mathrm{RN}$ et en motte. À la fin de la deuxième année cependant, l'avantage significatif des arbres endurcis sur les arbres en motte s'est estompé et les taux de croissance des arbres des deux méthodes étaient équivalents à ceux des arbres non transplantés, suggérant que la performance post-transplantation des arbres endurcis et des arbres en motte peut s'avérer similaire. L'application d'acide humique n'a affecté que les arbres $\mathrm{RN}$ de sorte que les arbres RN traités avec de l'acide humique avaient des indices de survie et de croissance plus élevés que les plants contrôle non traités. De manière générale en climat aride, le gestionnaire du site obtiendrait la méthode de transplantation la plus efficace et la plus fiable en plantant des thuyas en motte sans nécessité d'une période d'endurcissement et d'incorporation de stimulants.

Zusammenfassung. Der Mangel an Informationen über geeignete Bedingungen für die Verpflanzung von Bäumen in aride Klimaten ist der Hauptgrund für das Versagen von den meisten Pflanzprojekten. Diese Studie untersucht die Einflüsse von verschiedenen Pflanzmethoden und die Applikation von Biostimulantien auf das Überleben und Wachstum von einer orientalischen Thuja (Platycladus orientalis), die für viele Zwecke geeignet ist. Im ersten Experiment wurden die Bäume als Wurzelware geerntet oder balliert und eingeschlagen in Ballentuch und anschließend in Containern für ein Jahr vor der Verpflanzung abgehärtet. Im zweiten Experiment wurde die Performance nach der Verpflanzung der abgehärteten Container-Bäume verglichen mit frisch ausgegrabener Wurzelware oder Ballenware. In beiden Experimenten wurde die Hälfte der Bäume mit 300 mg/L Huminsäure (HA) behandelt. Im Gegensatz zu den ballierten Bäumen schien die Wurzelware den Abhärtungsprozeß nicht so gut zu tolerieren. Während des ersten Jahres nach der Verpflanzung zeigten die abgehärteten Bäume 100\% Überlebensrate und erzielten im Vergleich zu den ballierten oder wurzelnackten Bäumen in allen gemessenen Parametern einen signifikanten Zuwachs. Am Ende des zweiten Jahres jedoch verschwand der signifikante Vorteil der abgehärteten Bäume gegenüber den ballierten und die Wachstumsraten der Bäume beider Methoden war vergleichbar mit nicht-verpflanzten Bäumen, mit dem Ergebnis, dass die finale Performance abgehärteter Bäume und konventionell ballierter und verpflanzter Bäume vergleichbar war. Die Huminsäureapplikation beeinflusste nur Wurzelware, so dass mit Huminsäure behandelte Wurzelware eine größere Überlebensrate und Wachstumssteigerungen hatten als ihre Kontrollen. Allgemein lässt sich sagen, dass der Garten- und Landschaftsbauer in einen ariden Klima mit der Pflanzung von ballierten Thuja-Pflanzen ohne die Notwenigkeit der Abhärtung und der Applikationen von Stimulantien die kostengünstigste und verlässlichste Methode erhält.
Resumen. La escasez de información sobre condiciones adecuadas para el trasplante de árboles en climas áridos es una causa importante del fracaso de la mayoría de los proyectos de trasplante. Este estudio investigó el efecto de diferentes métodos de trasplante y la aplicación de bioestimulantes en la supervivencia y el crecimiento de especies multiusos de thuja oriental (Platycladus orientalis). En el primer experimento, los árboles fueron cosechados a raíz desnuda (BR) o arpillados en bola (B \& B) y endurecidos en contenedores durante un año antes del trasplante. En el segundo experimento, se comparó el comportamiento de los árboles endurecidos en contenedores tras el trasplante (denominado CG) a los árboles recién cavados BR y B \& B. En ambos experimentos la mitad de los árboles fueron tratados con $300 \mathrm{mg} / \mathrm{L}$ de ácido húmico (HA). En contraste con los árboles B \& B, los árboles BR no toleraron con éxito el proceso de endurecimiento. Durante el primer año después del trasplante al paisaje, los árboles CG mostraron una supervivencia del $100 \%$ y lograron aumentos significativos en todos los parámetros medidos comparados con los árboles B \& B y BR. Al final del segundo año, sin embargo, la ventaja significativa de los árboles CG sobre el B \& B se desvaneció y las tasas de crecimiento de los árboles de ambos métodos fueron igualadas a los árboles no trasplantados, lo que sugiere que el rendimiento final para CG y árboles convencionalmente trasplantados puede ser similar. La aplicación de HA sólo afectó a los árboles BR, de modo que los árboles BR tratados con HA tuvieron mayores índices de supervivencia y crecimiento que sus homólogos de control. En general, en un clima árido, el gestor del paisaje obtendría el método de trasplante más rentable y fiable mediante la plantación de thujas en B \& B sin necesidad de un período de endurecimiento e incorporación de estimulantes. 